THURSDAY, APRIL I4, I88r

\section{THE NEW MUSEUM OF NATURAL HISTORY}

THE

HE great terra-cotta building facing Cromwell Road, South Kensington, and occupying the site of the old 1862 Exhibition, about which for the past twelve montbs public curiosity has been raised, is about to draw up its blinds, and to offer a part of its extensive galleries for inspection on Easter Monday.

It is no secret that for thirty years past the accommodation in the British Museum, Great Russell Street, Bloomsbury, "both for man and beast," had become too restricted, and the necessity for a larger building was keenly felt. As usually happens in such cases, the most adventurous and energetic officer was the first to obtain for his department what he required, namely, more room.

Sir A. Panizzi (then Keeper of Printed Books) projected, shortly after the 185 I Exhibition, his scheme for a great central Reading-room and Library, and some five years after witnessed its completion. Some years later on, the Department of Antiquities, represented by Mr. C. T. Newton, C.B., also obtained an addition to its galleries on the western side, and still more recently on the southern side, next the great Entrance Hall.

Great praise is due to Mr. Bond, the present Principal Librarian, for putting an end to the use made of the fine colonnade in front of the British Museum, which for twenty-five years was blocked by antiquities covered in with a row of extremely unsightly and incongruous wood and glass sheds. These are now happily removed. The Department of Prints and Drawings lacking a gallery, obtained possession of the "King's Library" floor on the east side for an exhibition space; and even the conservative Coin Department likewise laid out for the public a few show-cases here of coins and medals.

But, like the clothes of the rising son, in the old caricature, the collections everywhere had outgrown their receptacle, and none more so than the departments of Natural History. Scientific men were however not unanimous, and a fierce controversy was carried on in $1858-59$ as to the relative merits of enlargement on the old site, or dismemberment. Finally, after a Committee of the House of Commons had taken evidence upon the subject, the removal of the Natural History Collections was decided upon by Government.

But the death of the Prince Consort, the delay of the House of Commons to vote the necessary funds, the retirement of Sir A. Panizzi from the post of Principal Librarian, the discussion of rival plans, the inevitable delays about the completion of any Government building, caused twenty years to pass before the plans of the chosen architect, Mr. Alfred Waterhouse, were realised in a solid and material form.

Midsummer, 1880 , barely sufficed to enable the Office of Works to certify to the fulfilment of the Contractor's work and to hand over the building to the Trustees ere collections began to be moved in.

Nine months only have elapsed, and already three Departments, viz. Botany, Mineralogy, and Geology, have transferred their entire collections from the old to Vor. XxIII.-No. 598 the new building. But less than half the cases for the entire building have yet been supplied, and everywhere the labour of completing the structure as well as fixing cases and fittings is being busily carried on. Under these circumstances it seems not improbable that two years may elapse before the Zoological Collections will be removed and housed in their new quarters.

Let us now take a glance at what Mr. Sala styles "this Temple of Nature." The architectural character of the new building may be termed "Decorated Norman," but it is in many respects unique, especially as regards the treatment of its details. The first, or "ground-floor," is above the road, and the entrance is approached by a broad flight of steps and by a sloping carriage-drive. The entire structure is of brick cased with terra cotta, the doorways and the windows being ornamented with columns designed from natural history objects, chiefly from plants. Reproductions of various animals are also introduced. The main part of the building has a tower at each end, and there are also two central towers rising on either side of the entrance. The south front of the building is about 650 feet in length, running due east and west, and is three storeys high, in addition to the basement, which is above the level of the garden in which the building stands.

The Central Hall or "Index Museum" runs from south to north; it is 150 feet long, 97 feet wide, and about 60 feet high; along its two sides are twelve arched recesses. At the north end is a wide and handsome staircase which branches off right and left to the open corridors or side aisles on either hand upon the first floor. This Central Hall is more richly decorated than any part of the building. The floor of mosaic work, where Italian marble is employed, has been skilfully laid by Italian workmen. The side aisles or corridors look out into the Central Hall by an open balustrade surmounted by large arches, each containing three smaller ones, the centre one being much higher than the others. The pillars supporting these are ornamented with a nearly natural treatment of Lepidodendron; in some few cases animals, monkeys, birds, \&c., are introduced. The decoration of the ceiling is very effective. A double row of panels runs along the central line, and on either side of this, between the iron girders and following the curve of the roof, are panels in groups of six ; these are ornamented with representations of different species of trees, shrubs, and flowering-plants treated somewhat conventionally. That portion of the ceiling over the main body of the hall is decorated with trees, each of which occupies six panels, as they can be most easily scen from the floor and need bold treatment. At the south end, where the ceiling is over a staircase and landing leading from the first to the second floor, each panel contains but one species : the eye being nearer to the ceiling greater detail has been introduced. The effect of the whole is very fine, and as the hall is at present without any cases or specimens, it has the general appearance of a cathedral. This idea is further heightened by the introduction of a triforium, though this has been added merely for effect. the passages being interrupted.

Beyond the Index Museum is a smaller and less lofty hall quite divided from it, save by two arched entrances, 97 feet by 70 feet, intended to hold the British Zoological Collection. It is surrounded by arched recesses similar to those in the Index Museum. In this hall the decora- 
tion of the ceiling is also botanical, but all the species selected are of British plants. Underneath the staircases and in the recesses a plain light colour is introduced, relieved with gilding. The decorations of the saloons or galleries are much simpler. The columns throughout are of terra cotta, ornamented with natural history objects.

The other parts of the building consist of series of galleries running north from the front or main building, but only one storey above the basement. The rooms on each floor, at the end of the long front galleries and under the two end towers, are called pavilions. The main or front galleries facing Cromwell Road are lighted by windows north and south. The Central Hall or Index Museum, the Hall for British Zoology, and all the other galleries of one storey high running north, are lighted by skylights. The Index Museum has however, in addition to its roof-lights, windows in the corridors on either side.

The distribution of the space available is as follows :The long galleries to east of the entrance on the groundfloor, and all the galleries from it, running north, are devoted to Geology and Palæontology. The first fioor above the Geo. logical Gallery is devoted to Mineralogy, and the floor above this to Botany. The whole of the galleries on the west side of the building are given to Zoology. The Index Museum, according to Prof. Owen, is designed to present to the public, in a series of twelve recesses, typical examples of all the collections-in fact, an epitome of the whole animal, vegetable, and mineral kingdoms. Prof. Owen further desires to show the marvels of nature and objects of special interest, as exemplifying size, \&c., such as whales, basking sharks, \&c. These are to occupy the centre of this great hall. Passing to the right from the Index Museum (on the ground floor) we enter the South-East Gallery of the Geological Department (233 feet in length by 50 feet in width, and lighted by windows on either side), at the east end of which is the. Pavilion, a room 60 feet by 40 feet. These two galleries are entirely devoted to the exhibition of the fossil Mammalia and Birds, and are provided with pier-cases and table-cases. The larger objects are arranged down the centre of the floor.

The cases on the left hand are nearly all occupied with the remains of Proboscidea. Commencing with the Deinotherium from Epplesheim, with its tusk-like incisors in the lower jaw, we pass to the Mastodons, in which, as a rule, the tusks are developed in the upper jaw and not in the lower. But to this there are exceptions; one American Mastodon having immature tusks in the lower jaw, and the Mastodon augustidens, from Sansau in France, having tusks in both the upper and the lower jaw.

Nearest the entrance door, in the centre of the gallery, is placed the entire skeleton of the great American mastodon from Ohio, which must have been considerably larger in bulk than that of any existing elephant; on the same stand is placed the head of a young Mastodon from New Jersey, and in front of it the skull and lower jaw of the South American Mastodon from Chili. It is interesting to notice that both the mastodon and elephant had overspread the North and South American continents in Tertiary times, and they were equally widely distributed over the European and Asiatic continents; their modern representatives however are confined, the one to the continent of Africa, the other to India, Ceylon, \&c. The tusks of some of the old fossil elephants were of enormous proportions : witness the head of Elephas ganesa from the Siwalik Hills, India, and that of the mammoth (Elephas primigenius) from the valley of the Thames, near Ilford. Large numbers of elephant remains have been dredged up year by year for the past sixty years off the Dogger Bank and the Norfolk coast, affording good evidence that in comparatively modern times the North Sea was a great valley watered by the Rhine, Moselle, \&c., giving pasturage to vast herds of deer, bison, oxen, and elephants; where also the rhinoceros and the hippopotamus found a pleasant home. A goodly series of the remains of these animals from British and Continental localities may be seen in this gallery, and also abundant evidence of the old Siberian mammoth and rhinoceros, both of which have been met with "in the flesh," frozen solid in mud and ice. Here are also exhibited an interesting series of the "pigmy elephant" from Malta, brought home by Admiral Spratt, R.N., and Prof. Leith Adams. By far the larger collection of elephant remains are those from the Siwalik Hills, India, obtained by Col. Sir Proby T. Cautley and described by Dr. Hugh Falconer, F.R.S. The "gigantic Irish deer" (Megaceros Hibernicus) forms a prominent and striking object in the centre of the gallery, with its branching antlers Io feet across, a noble prey for its contemporary, the "sabre-toothed tiger" (Machairodus latidens), remains of both animals having been found together in Kent's Cavern, Torquay.

Passing by the cases of carnivora, of thick-skinned animals, and of ruminants, our attention is next arrested by the great bandless armadillo from South America (Glyptodon), whose carapace is bigger than a hogshead, and which measured nearly 12 feet from its head to the tip of its armour-plated tail.

Another of these extinct Edentates from the La Plata, the Megatherium Americanum, stands in the centre of the floor of the Pavilion. This colossal "ground-sloth" measured 18 feet in length, its bones being more massive than those of an elephant. It displays in every part of its framework enormous strength and weight combined, sufficient to break down or uproot the trees, upon the leaves and succulent branches of which it fed, like its pigmy modern congener Bradypus tridactylus, which leads an arboreal existence, climbing from bough to bough in the Brazilian forests.

The extinct Marsupial fauna of the great island continent of Australia is here well represented by the huge Diprotodon, the Nototherium, and the anomalous Thylacoleo. Of the Wombat family only a small living representative is known, of burrowing habits, found in Tasmania ; formerly they were abundant on the continent of Australia, varying in size from a marmot to that of a tapir. The largest of these are called Phascolomys magnus and $P$. gigas.

The collection of remains of the great extinct wingless birds of New Zealand forms a very interesting feature of this gallery. The tallest skeleton measures 12 feet in height, and the smallest not more than 3 feet.

Madagascar had also its extinct wingless birds, similar to those of New Zealand. Eggs of both the Dinornis and the Apyornis may here be seen, one of the latter having a capacity of two gallons.

The rarest of all avian fossils is still the Archaopteryx 
macrura from the lithographic stone quarries of Solenhofen. Fortunately for the incredulous a second specimen has recently been obtained, and is preserved in the Berlin Museum. Its lacertilian affinities are well shown in its long and rat-like tail of twenty vertebræ and its three-clawed digits in each fore-limb (or wing?). The head of the Berlin specimen is too obscure to give evidence of teeth, but its beaked jaws are clearly seen in the photograph. The original specimen described by Prof. Owen is headless.

Running parallel with the south-east gallery is the Reptilian Gallery, 225 feet in length and $2 \mathrm{I}$ feet wide, the south wall of which is entirely occupied with the grand series of sea-lizards, the Ichthyosauria and Plesiosauria, once so abundant in the old Liassic seas of Europe, and the fossil remains of which have even been brought home from the Arctic regions and from New Zealand. The largest of the long-necked Plesiosaurs measures 22 feet in length and 14 feet across its extended paddles. The largest Ichthyosaur was probably even bigger than this. On the north side are displayed the remains of the great land lizards, Dinosauria, of which the Iguanodon is perhaps the most familiar example. A more recent discovery is that of the Omosaurus from the Kimmeridge Clay of Swindon, Wilts, the femur of which is more than 4 feet in length, and the humerus nearly 3 feet long, and enormously broad; they were probably to some extent amphibious in their habits, but their limbs were well fitted for progression on the land.

Numerous other fine Dinosaurian remains are to be seen in these cases. As we do not know the teeth of many of these huge reptiles, we are unable to speak positively as to their habits; but it is certain that from the Trias to the Chalk two groups have existed side by side, one having a carnivorous dentition and the other being herbivorous. The Teratosaurus of the Trias of Stuttgart and the Lycosaurus and Cynodraco from the Cape, the Megalosaurus of the Stonesfield Slate and Wealden were all carnivores, whilst the Iguanodon, Acanthopholis, Scelidosaurus, and the South African genera Anthodon and Nythosaurus were all vegetablefeeders. But of Polacanthus, Omosaurus, Hylaosaurus, and Cetiosaurus we have no direct dental evidence. No doubt, as amongst the mammalia at the present day, the majority were vegetable-feeders and the minority were predacious in habit.

In this gallery are also exhibited the flying lizards of the Secondary Rocks, most of which have been found in the lithographic stone of Solenhofen and a few in our own Lias, Stonesfield Slate Chalk, and Greensand.

If Comparative Anatomy may be trusted, some of the Pterodactyles from the Chalk of Kent give evidence of a flying lizard having probably an expanse of wings of from eighteen to twenty feet.

An Australian novelty is the great horned lizard ( $M e g a$ lania prisca), $\mathrm{I}_{4}$ feet or more in length, with nine hornlike prominences on its skull and an armour-plated tail similar to that of the Glyptodon.

The Triassic reptiles from South Africa form a singular addition to our knowledge of ancient life forms long since passed away. They are comprised in Prof. Owen's groups of Anomodontia and Theriodontia.

Among the fossil Chelonians we have representatives of both the marine turtles, the fresh-water Trionyx and Emys, and the gigantic and lesser land-tortoises. Of the first of these are the remains of the great Chelone Hofmanni from Maestricht, and the Chelone gigas from the London Clay of Sheppey, larger by far than the "loggerhead" turtle of the present day. Of the last (landtortoises) may be mentioned the Colossochelys atlas from the Siwalik Hills, which out-rivals the Glyptodon in bulk.

Three wide and four narrow galleries built at right angles to the Reptile Gallery, each 137 feet in length, the former being 40 feet and the latter 20 feet in width, are placed alternately, running due north and south, and lighted from above. These fine rooms afford ample accommodation for the fossil fishes, all the classes of the Invertebrata (mollusca, brachiopoda, bryozoa, insecta, myriopoda, arachnida, crustacea, annelida, echinodermata, corals, foraminifera, sponges, and plants). These long galleries, or annexes, and the ones corresponding with them on the western side, are built upon the plan recommended by the Royal Commission of 1874 . But the wall-cases are all constructed to open in front, not at the back of the case, as suggested. They are however the best-lighted galleries in the whole building, and best suited for museum purposes. Two of these large galleries are not yet ready for occupation, and the third is under arrangement; the narro" galleries give space for a library, special reference collections, a stratigraphical series, and working-rooms for students.

In the basement are twelve workshops, studies, and store-rooms devoted to Geology, ten studies, work-rooms, and laboratories to Mineralogy, and three to Botany.

The Mineralogical Gallery, on the first floor, which corresponds with the South-East Gallery and Pavilion in extent, is also lighted by windows on either hand; it has seven wall-cases, two at each end of the long gallery and three in the Pavilion, the collection being mainly contained in forty-eight large table-cases.

These table-cases form a long row on either hand, commencing at the entrance of the gallery, the odd numbers being on the left band and the even on the right. Each of the first forty cases nearly equals in capacity two of the cases in the old mineral gallery; we have therefore a much more magnificent display than could have been attempted formerly, when the minerals and fossils were all crowded together in the same gallery.

The collections of naturally and artificially-prepared crystals occupy two large cases in the Pavilion, whilst two of similar construction are filled with meteorites. The great Cranbourne Meteorite and that from Mexico occupy special cases on the east side. In the wall-cases are arranged the extensive collection of rocks, two cases being devoted to polished marbles.

The general plan pursued in the arrangement remains the same as in the old Museum gallery, so that by using boxes corresponding to one quarter of a table-case, the minerals were transported from the old to the new building and re-arranged in an incredibly short space of time, and with the exception of the Pavilion and the wall-cases have long been ready for exhibition.

In the Botanical Gallery the glazed cases for the exhibition of specimens project from the wall into the room like square shop-fronts, having three plate-glass sides. The whole of the glass is permanently fixed, except one 
division forming the door. A "cell" inside, inclosed by curtains, gives access to the specimens; by this contrivance it is hoped that the dust will be excluded to a great extent.

Accommodation for large specimens, as, for example, portions of stems and sections of various kinds of wood, such as oak, walnut, pine, cedar, and other dicotyledons, and trunks of palms, cycads, tree-ferns, bamboos, and other striking examples of the vegetable kingdom, is provided for by three tall metal and glass cases I4 feet high, occupying the floor-space in the centre of the gallery.

One-half of the main gallery is partitioned off from the public room, and fitted up with cabinets for the reception of the Herbarium, the nucleus of which was obtained by Sir Joseph Banks and Solander in their voyage round the world with Captain Cook. This first series of cabinets is entirely occupied with the flowering plants, which are all fastened on single sheets of paper. The Pavilion contains similar cabinets for the reception of the British plants and Filicinæ, whilst the room above in the tower is intended for the Cryptogamia. Down the centre of the large room are cabinets fitted to receive the great collection of fruits and seeds, each being placed near its appropriate family in the Herbarium on either side. These inner rooms, with the valuable library attached to them, are of course only available for purposes of study, but are always accessible to the botanical student and worker.

On the south-west side of the Index Museum, the gallery on the second floor which corresponds with that appropriated to Botany is designed to contain the great collection of Recent Osteology; that on the first floor is to be devoted to stuffed animals, and the front groundfloor gallery to birds. The eight galleries in rear of the main building on the west side will be appropriated to the Reptilia, Fishes, and Invertebrata. The collections preserved in spirits are to be placed in a special building at the north erid of these galleries. The basement on the west side contains sixteen studies and work-rooms and a large open space well fitted for workshops and stores.

The Assistant-Secretary (Mr. J. T. Taylor) is provided with offices adjoining the Board Room on the first floor above the British Zoological Hall. The Superintendent, Prof. Owen, C.B., and the Keepers of Geology (Dr. H. Woodward, F.R.S.), of Mineralogy (Mr. L. Fletcher, M.A. F. G.S.), and of Botany (Mr. W. Carruthers, F.R.S.), have each a study in the central towers on either side the entrance.

There are a few scientific men who still strongly protest against the removal of the Natural History Collections from the old to the new building, on the ground that the locality is inconveniently far west, and that they are thereby precluded from using the Collections so freely as heretofore. One of the strong grounds for protesting against the removal has been the serious inconvenience arising from the separation of the collections from the great National Library. This injury will however be gradually removed by the formation of a new Natural History Library in the present building, a vote for which has been already taken.

The comparatively small band of scientific men who use the Natural History Museum for purposes of special wark and study, wauld always do so wherever the collections happened to be located.
So too the holiday-makers, who come to the Museum merely to be amused, will as willingly travel to South Kensington as to the Regent's Park Zoological Gardens, or to the Crystal Palace.

Undoubtedly the highest aim and use of our great National Natural Historical Collections should be to impart instruction to the young and rising generation, and afford every facility for the advancement of our scientific students, and the question whether they are now conveniently placed is mainly for them to answer. If in the future South Kensington is to become a great centre of scientific instruction, then, and not otherwise, the Natural History Collections have been placed in their most suitable position.

We cannot conclude this hasty notice without stating that the old restrictions as to days of admission have all been swept away, and the collections will from and after the 18 th be open daily to the public, save on Sundays, Christmas Day, and Good Friday, and other public fast days, \&c. ; good and cheap guide-books are also to be ready for the $I 8$ th.

For this and other concessions the public are mainly indebted to the untiring energy and determination of the present principal Librarian, Mr. Edward A. Bond, LL.D., who has also been the means of introducing many necessary and useful reforms into the old building; not the least being the electric light, which it may be hoped will ere long cast its beams over the collections in the Natural History Museum, Cromwell Road, South Kensington.

\section{TEXT-BOOK OF MECHANICS}

A Text-Book of Elementary Mechanics, for the Use of Colleges and Schools. By Edward S. Dana, Assistant Professor of Natural Philosophy in Yale College. (New York: John Wiley and Sons, I881.)

THIS is a small-sized book of 290 pages printed in 1 fairly clear type, and bound in an unpleasantlooking cover, and we learn from the preface that it has been prepared to meet the special wants of Yale College instruction. An endeavour has been made to dwell more fully than usual on the principles of the subject, at the same time illustrating these principles in their practical bearings by descriptions of various machines and appliances, while no mathematical knowledge beyond the rudiments of algebra and trigonometry is required. From this it may be presumed that the book is intended for a very elementary class of students, at a lower stage, if possible, than "Poll" men at Cambridge, or else that it aims at assisting self-education by supplying the place of a tutor. An undoubtedly good feature in the book is the collection of examples, some of which are interspersed in the text, and others collected in a body at the end, where the answers are given. The metrical and ordinary units are both employed. These examples are perhaps the only part of the book which would be of any value to teachers in this country. With regard to the main subject-matter of the book, Dynamics is placed first, and Statics follows, with a chapter on the Pendulum at the end. The definitions and the explanation of the principles of the subject, though aiming at fulness and clearness, are not always so satisfactory as might he wished. A tendency to looseness of expression sometimes counter- 